Vol. 13, n² | 2009

Varia

\title{
Women's Prisons in Italy: A Problem of Citizenship
}

\section{Mary Gibson}

\section{OpenEdition}

\section{Journals}

Electronic version

URL: https://journals.openedition.org/chs/1106

DOI: $10.4000 /$ chs. 1106

ISSN: 1663-4837

\section{Publisher}

Librairie Droz

\section{Printed version}

Date of publication: 1 October 2009

Number of pages: $27-40$

ISBN: 978-2-600-01387-1

ISSN: 1422-0857

Electronic reference

Mary Gibson, "Women's Prisons in Italy: A Problem of Citizenship", Crime, Histoire \& Sociétés / Crime, History \& Societies [Online], Vol. 13, n² | 2009, Online since 01 October 2012, connection on 22 March 2022. URL: http://journals.openedition.org/chs/1106 ; DOI: https://doi.org/10.4000/chs.1106 


\title{
Women's Prisons in Italy: A Problem of Citizenship
}

\author{
Mary Gibson ${ }^{1}$
}

\begin{abstract}
Après l'unification italienne de 1861, le nouveau parlement italien promit une réforme du système carcéral répressif et arbitraire hérité des anciens États absolutistes de la péninsule. Cet article argumente que les réformes libérales destinées à moderniser et à laïciser la peine ne furent jamais étendues aux prisons pour femmes. Elles restèrent sous la tutelle des ordres de nonnes catholiques et empreintes du modèle conventuel, avec son insistance sur la conversion morale plutôt que sur la formation éducative et professionnelle. En outre, les autorités pénitentiaires romaines s'abstinrent de réclamer des sœurs de la charité une amélioration des conditions de vie dans des institutions fréquemment sordides. En négligeant la protection des droits «négatifs» des femmes détenues à un traitement humain et laïc qu'avait promise le Code Zanardelli de 1889, l'État italien refusait de reconnaître à ces dernières leur pleine citoyenneté.
\end{abstract}

After the unification of Italy in 1861, the new Italian parliament promised to reform the repressive and arbitrary prison system inherited from the former absolutist states of the peninsula. This article argues that liberal reforms intended to modernize and secularize punishment were never extended to women's prisons. Remaining under the administration of Catholic orders of nuns, Italian women's prisons continued to be modelled on the convent, with its emphasis on moral conversion rather than educational and vocational training. Furthermore, prison administrators in Rome failed to require the sisters of charity to improve living conditions in the often squalid female institutions. By neglecting to protect the "negative" rights of female prisoners to humane and secular treatment, as promised in the Zanardelli Penal Code of 1889, the Italian state refused to recognize their full citizenship.

Citizenship has become a major focus of global studies, and historians of Italian women have made important contributions to the exploration of the many ways in which women of the past were denied a variety of "positive rights" such as the right to education, property, and work; to control over their children

Mary Gibson is Professor of History at John Jay College of Criminal Justice City, University of New York, Publications: Translation (with Nicole Rafter) of Cesare Lombroso's Criminal Man (2006) and Criminal Woman, the Prostitute, and the Normal Woman (2004), Durham, N.C., Duke University Press; Born to Crime : Cesare Lombroso and the Origins of Biological Criminology, Westport CT, Praeger, 2002; Prostitution and the State in Italy, 1860-1915, $2^{\text {nd }}$ Edition, Columbus: Ohio State University Press, 1999; $1^{\text {st }}$ Edition, New Brunswick, NJ, Rutgers University Press, 1986. Her Current Research: Prisons of Rome: Punishment and Citizenship after Italian Unification. 
inside and outside of marriage; to divorce, contraception, and abortion; and to the acquisition or retention of Italian nationality as migrants across borders. In this exciting and expanding historiography about how and when women were gradually granted "positive" rights in the newly unified Italian state, little has been written about the juridical status of female criminals. At first glance, it may seem contradictory to attribute rights to persons who have broken the law and therefore have in some way put themselves outside of the social compact. Yet the provision of internal justice, like external defense, is a fundamental task of state-building, and the new constitutional states of the late eighteenth and nineteenth centuries hastened to reform their penal codes to incorporate the principles of political liberalism. These new penal codes, therefore, were meant not only to protect society but also to guarantee the rights of defendants during trials and require the humane treatment of accused and convicted prisoners.

Once unification was achieved, Italian statesmen were particularly concerned to overcome the reputation of the former regimes of the peninsula for their often corrupt, arbitrary, and repressive legal systems. Prisons had become a special symbol of the backwardness of these absolutist monarchies, especially those of the Papal States and the Kingdom of Naples. Equating these prisons to medieval dungeons, former political prisoners wrote memoirs - which gained an international audience - denouncing their inhumane and squalid conditions ${ }^{2}$. With reform of the legal system a priority, the government appointed capable and knowledgeable experts - most notably Martino Beltrani Scalia and Alessandro Doria - to unify, reorganize, and in many cases rebuild the disparate penitentiary systems inherited from the old regime. Such men sought to convince the international community that the new Italian state was committed to protecting what I would label the "negative" rights of suspected and convicted criminals.

Did this promise to protect negative rights apply equally to men and women? Were there gender differences in the penal code and the organization of the prison system in liberal Italy? As yet, the literature on the development of the Italian prison system after unification is thin and does not directly address the question of gender. Guido Neppi Modona's long article of 1973 still provides our best overview of the history of Italian prisons during the late nineteenth and early twentieth centuries but it does not mention women's institutions. Gender analysis is also absent from John Davis' rich analysis of law and order nineteenth-century Italy as well as Susan Carrafiello's short book on prison reform in the liberal era. Research on prisons in the old regime states is much richer and includes a pioneering study of women's prisons, with an emphasis on Turin, by Simona Trombetta ${ }^{3}$. Anna Capelli's analysis of prison reform during the Restoration touches on gender issues as do several articles in collections by Livio Antonelli and Mario Da Passano on early modern Italian prisons. In contrast to this growing body of work on early modern punishment, the historio-

2 For examples of memoirs by political prisoners, see Castromediano (1895), Carpi (1884); AAVV (1859).

3 Early modern Italy also boasts a rich historiography on "conservatories" for poor or "fallen" girls, which constituted the model for later women's prisons. For excellent examples, see Cohen (1992); Groppi (1994). 
graphical silence on women's prisons after unification mirrors the neglect of female prisoners during the first fifty years of Italian unification ${ }^{4}$.

The first unified criminal code, the Zanardelli Penal Code of 1889, was surprisingly equalitarian in regard to the rights of defendants, the definition of legal responsibility for breaking the law, and the prescriptions for punishment. Its delayed adoption followed decades of serious debate in parliament and among legal scholars about how to imbue Italian criminal law with the enlightenment principles that informed the justice systems of nations such as France and England. These principles, first systematically articulated in Cesare Beccaria's famous treatise On Crimes and Punishments (1764), included equality before the law, the presumption of innocence for defendants, and proportionality between punishment and the crime. In its implementation of these principles, the Zanardelli Code made few mentions of women and, therefore, appeared relatively gender-neutral.

There were a few exceptions, however, and women were singled out for distinctive treatment in sections of the code dealing with adultery, infanticide, and abortion. A man could bring accusations of adultery against his wife on a variety of often flimsy evidence while a woman could make a similar case only if her husband maintained "a mistress in the family home or elsewhere in a scandalous manner" 5 . Since adultery constituted the main grounds for legal separation, this inequality in the penal code exposed women more than men to the loss of home, income, and children. On the other hand, the code seemed to favor women accused of infanticide or abortion, crimes committed most often by women. If these crimes were committed "to save her own honor," then the sentence was reduced" 6 . Yet men also benefited from reduced sentences if they collaborated in either crime to protect the honor of their "wife, mother, daughter, adopted daughter, or sister" ${ }^{7}$. Thus women's diminished responsibility for infanticide and abortion was not a recognition of their right to control their sexuality but a means of protecting family honor.

The Zanardelli Code also mentioned women in the section on types of admissible punishments, although only briefly. First, the law allowed judges to sentence a woman convicted of a minor crime carrying a sentence of less than a month to undergo arrest in her house rather than in a prison ${ }^{8}$. Second, the law stipulated vaguely that women would be incarcerated in "special institutions" 9 . It failed to describe these prisons more specifically in order, according to one legal commentary, "to avoid listing special punishments for women"10. Wanting to leave an impression that the principles of punishment were universal, the framers of the

4 Research on women's prisons in other nations is more advanced. For France, see O'Brien (1982); Petit (1984). For England see Zedner (1991); for the United States see Rafter (1985); Freedman (1981).

5 Codice Penale Italiano [Italian Penal Code] (1889), Articles 353-354.

6 Codice penale (1889), Articles 369 (infanticide) and 385 (abortion). The sentence for infanticide "to save her own honor" was 3 to 12 years while the minimum sentence for homicide, mostly a male crime, was 12 years. In the case of abortion, the motive of honor brought a reduction of one to two thirds in the sentence. The standard sentence for women convicted of abortion was 1-4 years.

7 Codice Penale (1889), Articles 369 and 385.

8 Codice Penale (1889), Article 21. This concession was extended only to women who were not recidivists.

9 Codice Penale (1889), Article 23.

10 Pessina (1890, p. 70). 
Codice Penale left the delineation of these "special institutions" to future administrative laws.

The relative gender equality of the Penal Code was surprising in light of the clear subordination of women to men in the Civil Code of 1865. Popularly called the Pisanelli Code, this earlier legislation denied women many of the legal rights encompassed in the modern understanding of citizenship. Restrictions were most severe for married women, who were subject to the doctrine of autorizzazione maritale (marital authorization). Without the explicit and public consent of her husband, a wife could not "give gifts, sell or mortgage real estate, enter into a loan, offer or collect wages, [or] take out insurance..."11. In addition to controlling his wife's right to property and work, the husband was designated in the code as the "capo della famiglia" (head of the family) with sole power to discipline his children and manage their property ${ }^{12}$. A woman could exercise these rights of "patria podestà" (paternal power) only after the death of her husband and according to directives laid out in his will or by a "family council" 13 . The Civil Code was more equitable to single than married women but other legislation restricted the access of all women to education, employment in the professions and public administration, service on juries, and, of course, the right to suffrage.

In sum, the Penal Code, which assigned almost equal criminal responsibility to men and women, seems to have contradicted sharply the Civil Code, which placed women in a clearly inferior legal position to men. The apparent contradiction between the two codes, however, is partially resolved by considering the nature of those "special institutions" for the punishment of female criminals. Once convicted, women entered a different universe of punishment from that of men. Leaving the realm of the courts they entered another ruled by administrative regulations that were shaped to a large extent by prison personnel rather than jurists or even parliament. Two general administrative laws - which defined the hierarchy of penal institutions, the duties of administrators and guards, and the rights and duties of prisoners - were promulgated during the first fifty years after unification: the Regio Decreto sulle Case di Pena of 1862 (Royal Decree on Institutions of Punishment) and the Ordinamento generale della amministrazione carceraria of 1891 (General Ordinance on Prison Administration $)^{14}$. While these laws theoretically guaranteed the same treatment and protections to both sexes, in fact the experience of female inmates differed sharply from that of their male counterparts.

What was the reality of incarceration for women during the first fifty years after Italian unification? For both sexes, the penal system was comprised of three general

11 Codice Civile del Regno d'Italia [Civil Code of the Kingdom of Italy] (1865), Article 134. The doctrine on autorizzazione maritale (marital authorization) is comprised in Articles 134-37. It was not abrogated until 1919.

12 Codice Civile (1865) Article 131. In practice, of course, decisions about the upbringing of children were made by husbands and wives together. But in cases of dispute, husbands could enforce their will in court.

13 Articles 220-239 defined the powers of patria podestà in the Codice Civile of 1865.

14 The Reggio Decreto 17 gennaio 1862 on the penitentiaries was preceded by parallel decrees on the bagni penali (hard labor camps) (19 Sept. 1860) and the local jails (27 Janary 1861). In addition to the Royal Decree of 1862 and the Ordinance of 1891, a host of supplementary laws were issued dealing with personnel, juvenile reformatories, and legal innovations like "conditional release" for certain categories of inmates. 
types of institutions: prisons (case di pena) for those serving sentences of over two years; jails (carceri giudiziarie) for those serving sentences of less than two years or awaiting trial; and reformatories (case di custodia later designated riformatori) for minors under eighteen years of age ${ }^{15}$. Women's institutions made up only a marginal and heterogeneous sector of the larger prison complex. In 1881, for example, only 6 out of the 72 long-term prisons in Italy were for women ${ }^{16}$. These were located in Messina, Perugia, Rome, Turin, Trani, and Venice. Most of the 64 short-term jails housed both men and women, but the female sections were generally very small ${ }^{17}$. Only in the case of minors did the numbers of reformatories for girls (15) come close to that for boys (22). This relatively large number of girls' reformatories did not reflect greater criminality on the part of girls but instead resulted from the traditional policy of enclosing unprotected or unruly girls in conservatories, asylums, or other institutions modeled on the convent.

Perhaps more significant than their numbers was the unique administrative structure of penal institutions for women. All male prisons, except for some private reformatories for boys, were directed by lay administrators in the General Division of Prisons in the Ministry of the Interior and staffed by a uniformed "Corps of Guards" 18 . Made up entirely of men, the Corps of Guards for the prison system resembled the uniformed ranks of the urban Public Security police, in its hierarchical structure, its right to use weapons, and its direct subordination to the Ministry of the Interior. Although prison guards enjoyed much less pay, autonomy, or authority than their superiors in the administrative ranks, both groups enjoyed the protection of elaborate personnel laws regulating salaries, promotions, vacations, and sick leave $^{19}$. In contrast, the most important female penal institutions were managed by religious orders including the Sisters of St.Vincent de Paul, the Sisters of Providence of the Immaculate Conception, and the Sisters of the Good Shepard. Led by Mother Superiors, these orders supervised the female prisons, the largest female jails, and all the girls' reformatories. In 1877, at least 8 prisons and jails for adult women were supervised by religious orders, a number that rose to at least 14 by $1890^{20}$. These numbers do not include the reformatories for minor girls that, in 1881 , included one public and 14 private institutions ${ }^{21}$. Only in the case of jails were

15 At the time of unification, the bagno penale comprised a fourth type of institution for men and was under the jurisdiction of the Ministry of the Navy. The bagni were folded into the general category of the prison, and transferred to the jurisdiction of the Ministry of the Interior, in 1875.

16 Rivista delle discipline carcerarie (RDC), v. 11 (1881) contains a list of all Italian penal institutions in its Bolletino Ufficiale [Official Bulletin], pp. 96-102.

17 The exceptions were prisons for exclusively male convicts, like the bagni penali.

18 A very small number of institutions for adult men, like the agricultural colony at the Tre Fontane in Rome, were administered by monks but in conjunction with the Corps of Guards.

19 Members of the Corps of Guards were working-class men, often with military backgrounds. In contrast, administrators were required to have advanced education and came from the middle classes.

20 Archivio Centrale dello Stato (ACS), Ministero dell'Interno (M. Int.), Direzione Generale delle Carceri (DGC.), Archivio generale, Atti amministrativi, (1896-1905), b. 78, f. 1-A contains a list of religious orders assigned to women's prisons in 1877. This list is incomplete because it omits Rome, where the Good Shepard had renewed its contract in 1872 to oversee the jail for women, popularly called the Mantellate. For 1890, see ACS, M. Int., DGC, Arch. gen., Atti amm. (1896-1905), b. 78, f. 64 .

${ }^{21} \quad R D C$, v. 11 (1881), pp. 98, 101-102. 
female inmates more often under the supervision of male directors rather than sisters of charity. Both types of institutions - those administered by female religious orders and by male directors - employed female lay guards (guardiane), but these women held a lower status and received much lower pay than did male guards. Often the wives of male guards, the female lay guards mostly did the work of domestic servants.

It is difficult to uncover realities of prison life for women in this gendered world of punishment. Debates raged periodically in the press about questions related to male prisoners such as the advisability of deportation for habitual criminals, of agricultural colonies for redeemable criminals, or of internal exile (domicilio coatto) for suspicious persons. Yet female criminals seemed to have been forgotten for decades until several articles unleashed a torrent of denunciations of the conditions in women's institutions. One was by Marchesa Zina Centa Tartarini who wrote under the pseudonym of "Rossana"; she published her exposé entitled "Penal Institutions for Women" in the widely-read cultural magazine Nuova Antologia (New Anthology) in $1912^{22}$. Not simply a journalist, Rossana had been appointed as a volunteer inspector by the Director General of Prisons in Rome, and her reports on female prisons can still be found in the records of this office at the Central State Archive in Rome. A strange combination of women's activist and criminal anthropologist, Rossana was praised by one male prison director for "her intelligent industry... [and]... her really modern principles" ${ }^{23}$. Although critical of the conditions of female inmates, she was considered moderate enough by the prison administration to air her views in its official bulletin, the Rivista delle discipline carcerarie [Review of Prison Sciences] ${ }^{24}$.

Rossana's critique was based on many hours of observation in women's prisons and girls' reformatories, especially those of Perugia. Despite her role as a volunteer inspector for the Director General, Rossana accused the central government of taking little interest in female prisoners. She claimed that women's prisons, hardly mentioned in the Ordinance of 1891, were governed by only brief contracts made between the Director General and religious orders in various cities ${ }^{25}$. Once the contract was signed, the sisters ruled over the quality of food, clothing, and medical care given to the inmates with little oversight from the central state. In most women's prisons, the sisters served as prison contractors (appaltatori) and therefore held the power to stipulate types of work and rates of pay within the prison ${ }^{26}$. Although the Ordinance of 1891 required monthly meetings of a "discipline council" in each prison to rule on punishment for misbehavior and to recommend extra recompense for meritorious work, such councils rarely met in women's institutions. Instead, Mother Superiors unilaterally made such decisions ${ }^{27}$. Most disturbing to Rossana was the absence of regular schools or well-stocked libraries in female prisons and

\footnotetext{
22 Rossana (1912).

23 ACS, Ministero di Grazia e Giustizia (MG\&G), Direzione Generale delle Istituzioni di Pena (DGIP), Archivio generale, Atti amministrativi (1906-1925), b. 190, f. 46.

24 Her contributions to the $R D C$ included a "referendum" on the use of force to restrain violent prisoners; see $R D C$, v. 33 (1908), pp. 137-191.

25 Rossana (1912, pp. 259-260).

26 Rossana (1912,pp. 663-664).

27 Rossana (1912, p. 664).
} 
girls' reformatories, even though both services were required by the Ordinance of $1891^{28}$.

Because of neglect by state authorities, women's prisons were, according to Rossana, dilapidated and demoralizing. Situated in crumbling ex-convents, they lacked the architectural modernization typical of many male institutions. Women had to spend their daily hour of recreation in small paved courtyards rather in the gardens or meadows more typical of men's prisons. Mealtime was humiliating, with some women having only a stool on which to eat. Afterwards, they all waited in line to wash their cups and bowls in the same pan of hot water which became "an unspeakable broth" ${ }^{29}$. Even more degrading was the requirement to wear "the fatal bonnet" with a colored badge indicating the gravity of the punishment: red for short sentences, green for longer sentences, and black for life (ergastolo $)^{30}$. Such bleak surroundings and constant humiliation led to rebelliousness which, according to Rossana, took the form of "bad humor, despair, attempted suicide, or a flat and Jesuitical resignation" as well as simulated illness or madness ${ }^{31}$.

The article by Rossana was of course not completely reliable as historical evidence because she possibly exaggerated the wretched conditions at women's prisons, ignored positive initiatives by the sisters, or naively believed all complaints voiced by inmates. Yet her observations are generally supported by a variety of documents produced by the very prison administration that she was criticizing. These documents include national legislation, contracts between the state and religious orders managing women's prisons, reports by prison inspectors, and correspondence among the Director General of Prisons in Rome, provincial prefects, and local directors of men's prisons. Most of these sources demonstrate that the state at best neglected female prisoners and at worst did not assure them equal treatment to male prisoners.

Rossana was correct to point out that the Ordinance of 1891, like the Royal Decree of 1862 before it, devoted little space to the "special institutions" for the punishment of women. In the Royal Decree of 1862, only 14 out of 558 articles referred explicitly to religious administrators of women's prisons ${ }^{32}$. The Ordinance of 1891, despite being such a mammoth piece of legislation that it was published as a separate book, devoted even less space to women's institutions: 13 out of 891 $\operatorname{articles}^{33}$. For the most part, the two laws were identical. Both allowed for the

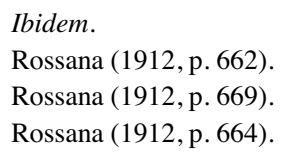

Ibidem.

Rossana (1912, p. 662).

Rossana (1912, p. 669).

Rossana (1912, p. 664).

RD 1862, Articles 84-93; 99-102. Articles 94-98 outlined services that sisters of charity might be asked to carry out in men's prisons - such as cleaning the buildings and maintenance of food and clothing - but government statistics do not show any female religious personnel assigned to male institutions.

33 Direzione Generale delle Carceri, Ordinamento generale della amministrazione carceraria, Roma, Tipografia delle Mantellate, 1891, Articles 148-160. The Ordinamento was too long to be included in the Leggi e decreti del Regno d'Italia [Laws and Decree of the Kingdom of Italy] and instead was published separately in two volumes. The first volume included the Regolamento generale $\mathrm{n}$. 260, which superceded the Reggio Decreto 1862, and a separate regulation limited to male personnel. The second volume is composed exclusively of the multitudinous forms that prison directors were required to fill out. 
employment of "sisters of charity" as personnel in women's prisons and gave the Mother Superior authority over the daily management of the institution ${ }^{34}$. The sisters were allowed to live according to the rules of their order as long as they carried out their duties and were obedient to the Mother Superior ${ }^{35}$. These duties would be defined by special contracts between the Director General in Rome and the Mother Superior $^{36}$. The latter was supposed to keep the director of the local male prison, technically her superior, apprised of daily activities in the prison, and he had the authority to overturn her decisions ${ }^{37}$. Yet, as we'll see below, male directors typically offered little oversight over the decisions of the Mother Superior.

Only a few articles differed between the two laws. The Royal Decree of 1862 directed the nuns to reform the women under their care, "avoiding, however, useless discussions, especially about what is taking place outside the institution" ${ }^{38}$. Possibly this warning evinced anxiety that the sisters might pass down negative judgments about the new Italian state from their religious superiors and proselytize for the cause of the Church in the upcoming struggle for Rome. The Ordinance of 1891 did not include any mention of reform or other purposes of punishment. Instead, it emphasized the importance of keeping meticulous records, on forms provided by the state, particularly about expenditures and profits from the prison industries ${ }^{39}$. Thus the maturation of the Italian state brought increased concern for bureaucratic regularity but not for the female prisoners in its care.

As specified in the laws of 1862 and 1891, the Director General made individual contracts with orders of nuns to administer women's prison, jails, and reformatories. Yet these contracts were also short and failed, like the general laws, to give specific directions for the reform of female inmates. That little attention was devoted to drawing up these contracts is clear from the admission by the Director General that there was no set procedure for renewing the agreement with the sisters of the Good Shepard for administration of the girls' reformatory in Rome. Rather than reviewing the conditions at the reformatory, he simply suggested to the Prefect of Rome that the old contract be renewed ${ }^{40}$. The sisters of the Good Shepard also managed a second penal institution in Roman, the local female jail (the Mantellate), and their conventions of 1887 and 1895 with the state were brief and inadequate for protecting the rights of inmates. The contract of 1887 , for example, was only two pages long ${ }^{41}$. It designated that one of the sisters would serve as the Mother Superior, that each sister would receive 45 lira per month for her work, and that the nuns could employ female lay guards for "lowly tasks" ${ }^{2}$. Two articles instructed the religious personnel to obey national penal legislation and to report daily to the Director of the male section of the jail (Regina Coeli). While these stipulations implied a subordination of the sisters of the Good Shepard to the state, the contract does not attempt to limit

\footnotetext{
34 RD 1862, Articles 84, 85; Ordinamento 1891, Articles 148, 151.

35 RD 1862, Articles 88, 93 ; Ordinamento 1891, Articles 152, 155.

36 RD 1862, Article 84; Ordinamento 1891, Article 148.

37 RD 1862, Articles 86, 87; Ordinamento 1891, Articles 149, 151.

38 RD 1862, Article 192.

39 Ordinamento 1891, Article 51.

40 ACS, M. Int., DGC, Arch. gen., Atti amm., (1896-1905), b. 180.

${ }^{41}$ ACS, M. Int., DGC, Arch. gen., Atti ammin., (1896-1905), b. 78, f. 1-A.

42 Ibidem.
} 
the role of religious ideology in the management of the prison. The subsequent contract of 1895 , while slightly longer, covers mostly the same topics ${ }^{43}$. One additional article exhorted the sisters to pay taxes on all the goods manufactured in the prison; this provision, like the emphasis on bureaucratic record keeping in the Ordinance of 1891 , showed that the state was more interested in women's prisons as a financial resource than as a place of reform. In an era when the Italian state was struggling against the Church to take control of other social institutions like schools and charities, it is striking that contracts for women's prisons did not more strictly require nuns to implement reforms infused with the liberal values of the new parliamentary order. These might have included an emphasis on providing inmates with a solid secular education and with skills for the modernizing economy while strictly curbing the propagation of religious doctrine.

Despite the stipulation in contracts with the sisters of charity to implement the Royal Decree of 1862 and later the Ordinance of 1891, inspectors found frequent violations. Inspectors of women's prisons were of two types: either official delegates from the Ministry of the Interior in Rome or volunteer philanthropists, like Rossana, usually from the local community. The practice of asking wealthy and often aristocratic community members to visit prisons had a long tradition in Italian cities and recalled the mixture of religious and lay control over charitable institutions typical of the early modern era. Yet male prisons were inspected only by state officials, again showing the unwillingness of the Ministry of the Interior to devote resources to serious oversight of women's prisons. One positive aspect of this policy, however, was that occasionally women - like Rossana - could fulfill the role of volunteer inspector although they were legally barred from holding the high administrative post of government inspector.

Reports of both official and volunteer inspectors are filled with a litany of "irregularities" in the functioning of women's prisons. In 1906, for example, an inspection by Inspector Gaetano Cardosa found "many irregularities and various problems" at the women's prison in Perugia. The disciplinary committee had not met for over a year although, according to the Circular of 20 June 1903 from the Minister of the Interior, it was required to convene every four months. In 1907, an inspection of the women's prison in Venice identified a host of problems including the bad quality of the school for inmates, which met only once per week, and the absence of a library ${ }^{44}$. One prisoner who complained about the food was demoted to a job with less pay and was subjected to "many unjustified punishments" by the sisters. According to the inspector, fear of similar retribution discouraged other women from protesting bad conditions ${ }^{45}$. Two years later, another inspector faulted the Venetian sisters for not keeping accurate financial records and for underpaying the female inmates for their work ${ }^{46}$. Such problems were not corrected for, in 1910, Inspector Cardosa was again critical of the religious administration in Venice, charging that some nuns used violence against the inmates, the food was below required standards, inmates received low pay and few raises for their work, rest

\footnotetext{
Ibidem.

ACS, MG\&G, DGIP, Arch. gen., Atti amm. (1906-1925), b. 190, f. 67.

Ibidem.

Ibidem.
} 
periods in the courtyard were too short, and there was no school or library ${ }^{47}$. Cardosa's criticisms disturbed his superiors in Rome who had expected him to contradict an earlier report by Rossana which had seemed to them "a bit exaggerated in its description of the existing problems" ${ }^{48}$. Instead his observations confirmed hers.

Prison administrators in Rome often attributed these problems to the lax supervision of women's prisons by the local directors of men's prison, who nominally oversaw the religious personnel of female institutions. In 1907, the male director of prisons in Perugia sent a long and defensive letter to his superiors in Rome about the lamentable conditions in the girls' reformatory. Admitting that "radical reforms" were necessary to improve the physical and educational environment of the girls, he added that "I will do nothing" until after a further inspection ${ }^{49}$. Faced with such procrastination, an evidently exasperated Director General wrote "Bravo" in the margins of the director's report. In 1910, the Director General admonished the male director of the Venetian prisons, Alfonso Cassella, to visit the women's facility twice per week and exercise "regular and effective vigilance over the nuns and their work" ${ }^{50}$. But little must have changed because in 1911, the Director General complained that Inspector Cardosa had reported that Cassella "does not exercise sufficient surveillance" over the nuns, especially over the quality of the food for the inmates $^{51}$. He again ordered Cassella to inspect the prison several times per week rather than every 10-12 days as was his custom.

Violations of prison regulations stemmed not only from lax supervision by local male directors but also from resistance to secular oversight by religious orders. The nuns regularly tried to negotiate better terms when renewing contracts and sometimes adopted a combative tone in their correspondence with state administrators. In 1892, the Mother Superior of the women's prison in Venice contested the right of the male director of the local men's prison to inspect her facility, claiming that her contract of 1883 stipulated that only the Prefect could exercise such oversight. She also refused to implement the guidelines of the new Prison Ordinance of 1891 on food, clothing, medicines, and wages until her present contract expired in 1894, even after the Prefect gave her permission to make such changes "gradually in order to avoid disturbing in any way the management of the institution" ${ }^{2}$. Despite a final order from the Director General that she comply with the 1891 Ordinance, little seems to have changed. In 1907, a new male director of Venetian prisons complained that he could find out nothing about the profit that the nuns extracted from the prison because "the Sisters... repeat continually and without variation, the same sentences used during the negotiation for renewal of the contract" ${ }^{53}$.

In another example of resistance to state authorities, in 1902 the Mother Superior of the girls' reformatory in Rome criticized the new "Constitution", or contract, recently issued by the Director General for her institution ${ }^{54}$. Why did Article 1, she

\author{
Ibidem. \\ Ibidem. \\ Ibidem. \\ Ibidem. \\ ACS, M.G\&G, DGIP, Arch. gen., Atti amm. (1906-1925)b. 427, f. 63. \\ ACS, M. Int., DGC, Arch. gen., Atti amm. (1896-1905) b. 78, f. 68A. \\ ACS, M.G\&G, DGIP, Arch. gen., Atti amm. (1906-1925), b. 109, f. 67. \\ ACS, M.G\&G, DGIP, Arch. gen., Atti amm. (1906-1925), b. 177, f. 55.
}


asked, say that the reformatory will take the name "Good Shepard" when her order had already been in charge of it for fifty years? She was even more perturbed at the limited power conceded to her as chief administrator of the reformatory. Only one article of the Constitution referred to her as the "Female Director" while many more delineated the powers of a new local "Commission" and its male president, who were directed to oversee the work of the nuns. Protesting "the large number of bosses" outlined in this contract, she insisted that "it has been shown that, when left to us, things always go better" 55 .

Religious orders also exercised autonomy in the choice of personnel. The Mother Superiors of many women's institutions held long tenures as wardens but the staff under them shifted continually. At the Roman jail, at least 12 nuns retired between 1890 and 1900 while 21 were added to the religious staff ${ }^{56}$. Although final approval for changes in staff resided with the Director General, there is no evidence that he questioned the recommendations of the Mother Superior in Rome. Personnel decisions might even come from higher authorities in a religious order, as happened in Venice in 1895. On 20 November, the national director (Superiora generale) of the Institute of the Sisters of Charity, an order with its headquarters in Milan, informed the Director General that she was replacing Modesta Peccoretti with Elena Conti as Mother Superior of the Venetian women's prison. After the Director General of Prisons, without questioning the choice, informed the Prefect of Venice of this change, the national director revoked her decision. In her letter, she gave no reason for this retraction, noting only that the Director General "has always left me complete liberty to make changes in personnel" ${ }^{\prime 5}$. Thus, the religious hierarchy in each order seems to have dictated personnel decisions in the penal institutions under their control.

Evidence from government sources confirms for the most part the accusations of Rossana about the unequal treatment of female inmates. Women were denied negative rights of citizenship in the new Italian state by continuing to be incarcerated in the same prisons, jails, and reformatories inherited from the former absolutist states of the peninsula. As Simona Trombetta has written, these old regime states had based their penal policy "on sexual difference: men were identified with the secular world and women with the religious world" ${ }^{\prime 8}$. Immediately after unification, Italian statesmen focused their attention on reform of men's prisons by appointing capable administrators to the post of Director General, establishing a professional Corps of Guards (with its own school), constructing innovative radial penitentiaries, and expanding options for work and education for inmates. While conditions for incarcerated men were in no way ideal, there were lively and continuing debates in parliament and the press about strategies for transforming male prisons on the model of the most progressive institutions in northern Europe. Nothing of the sort happened for women, who languished in penal institutions rarely mentioned in the main jour-

\footnotetext{
55 Ibidem.

56 ACS, M. Int., DGC, Arch. gen., Atti amm. (1896-1905), b. 78, f. 56-A. These numbers are based on individual personnel forms issued by the General Divison of Prisons. The disparity between the number of nuns leaving and joining the staff of the Mantellate indicates that some of the forms approving retirements are missing from the archive.

57 M. Int., DGC, Arch. gen., Atti amm. (1896-1905), b. 78, f. 68-A.

58 Trombetta (2004, p. 36).
} 
nals of "prison science" or in the reports of the Italian delegations to the International Penitentiary Congresses.

Of course it would be wrong and simplistic to argue that female religious orders were incapable of running efficient and humane institutions. Conditions were not uniformly bad in all female penal institutions and some inspectors - both volunteer and official - praised the work of the sisters of charity. In 1899, Inspector Sampò found "the optimum cleanliness, order, silence and tidiness" at the Venetian women's prison. In 1909, a report by members of a "visiting committee" to the Reformatory of the Good Shepard in Rome expressed "feelings of frank admiration" for the management of the institution ${ }^{59}$. In 1912, a more nuanced report from the new male director of the Perugian prisons combined praise with skepticism about the women's facility. He was most impressed with the "exuberant plantings in the vegetable and flower gardens" and the vases of flowers that made the penitentiary "simply beautiful and consoling" ${ }^{60}$. Nevertheless, despite his initial impression that the "from the outside... everything functions well," he admitted that "it is difficult to penetrate the internal organization of the religious personnel to understand how they carry out their mandate" ${ }^{61}$.

Evidence of instances of good administration by the sisters of charity does not, however, demonstrate that women possessed the same "negative" rights as men, that is, equal treatment in punishment. The Beccarian principles, enshrined in the Zanardelli Penal Code, promised punishment that was secular and regulated by national legislation protecting the rights of inmates. Italian women enjoyed neither during the first fifty years after unification. They were therefore doubly marginalized from Italian society, both as prisoners and as women. Their neglect by the Italian state constituted one of the many ways in which women were denied citizenship in liberal Italy.

\author{
Mary Gibson \\ Professor of History \\ John Jay College of Criminal Justice \\ City University of New York \\ 445 W. 59th Street \\ New York, NY 10019 USA \\ mgibson@jjay.cuny.edu
}

\footnotetext{
59 ACS, M.G\&G, DGIP, Arch. gen., Atti amm. (1906-1925), b. 177, f. 55 (for reports of the both the visiting committees).

60 ACS, MG\&G, DGIP, Arch. gen., Atti amm. (1906-1925), b. 426, f. 46.

61 Ibidem.
} 


\section{REFERENCES}

AAVV (Ed.), Le prigioni più rinomate d'Italia [The most famous prisons in Italy], Florence, A spese degli editori, 1859.

Antonielli, L., (Ed.), Carceri, carcerieri, carcerati. Dall'antico regime all'Ottocento [Prisons, prison guards, prisoners: From the old regime to the nineteenth century], Soveria Mannelli, Rubbettino, 2006.

Capelli, A. La buona compagnia: utopia e realtà carceraria nell'Italia del Risorgimento [Good Company: Utopia and Reality of Prisons in Risorgimento Italy], Milan, Franco Angeli, 1985.

Carpi, L., Prigioni di Stato Borboniche/Prigioni di Stato Austriache, in Il Risorgimento italiano : biografie storico-politiche d'illustri italiani contemporanei [The Italian Risorgimento: Historical-political biographies of famous contemporary Italians], Milan, Antica Casa Editrice/Dottor Francesco Vallardi, 1884, pp. 531-547.

Carrafiello, S. B., "The Tombs of the Living”: Prisons and Prison Reform in Italy, New York, Peter Lang, 1998.

Castromediano, S., Carceri e galere politiche: memorie del Duca Sigismondo Castromediano [Political prisons and jails: Memoir of Duke Sigismondo Castromediano], Lecce, Editrice Salentina, 1895.

Cohen, S., The Evolution of Women's Asylums since 1500, New York, Oxford University Press, 1992.

Davis, J.A., Conflict and Control: Law and Order in Nineteenth-Century Italy, Atlantic Highland NJ, Humanities Press, 1988.

Da Passano, M., (Ed.), Le colonie penali nell'Europa dell'Ottocento [Penal Colonies in Nineteenth-Century Europe], Rome, Carocci, 2004.

Direzione Generale delle Carceri, Ordinamento generale della amministrazione carceraria, Roma, Tipografia delle Mantellate, 1891.

Freedman, E., Their Sisters' Keepers : Women's Prison Reform in American, 1830-1930, Ann Arbor, University of Michigan Press, 1981.

Gibson, M., The Incarceration of Italian Women in Historical Perspective, in Messina, E.M., (Ed.), In Our Own Voices: Multidisciplinary Perspectives on Italian and Italian American Women, Boca Raton, Bordigiera Press, 2003.

Giulianelli, R., L'industria carceraria in Italia : lavoro e produzione nelle prigioni da Giolitti a Mussolini [Prison Industry in Italy: Work and Production in Prisons from Giolitti to Mussolini], Milan, Franco Angeli, 2008.

Groppi, A. I conservatori della virtù : donne recluse nella Roma dei Papi [Conservatories of Virtue: Interned Women in Papal Rome], Rome-Bari, Laterza, 1994.

Melossi, D. Pavarini, M., The Prison and the Factory: Origins of the Penitentiary System, London, Macmillan, 1981 (orig. Bologna, Il Mulino, 1977).

Neppi Modona, G., Carcere e società civile, in Storia D'Italia, Turin, Einaudi, 1973, vol. 5, part 2, p. 1903-1998.

O'Brien, P., The Promise of Punishment: Prisons in Nineteenth-Century France, Princeton, Princeton University Press, 1982.

Pessina, E., Il nuovo Codice Penale Italiano con brevi note dilucidative [The New Italian Penal Code with short explanatory notes], Milan, Hoepli, 1890.

Petit, J-G., (Ed.), La prison, le bagne et l'histoire, Paris, Méridiens, 1984.

Rafter, N. H., Partial Justice: Women in State Prisons, 1800-1935, Boston, Northeastern University Press, 1985.

Rossana, Case penali per donne [Women's Prisons], Nuova Antologia, 1912, 62, pp. 659-670. 
Spierenburg, P., The Prison Experience: Disciplinary Institutions and Their Inmates in Early Modern Europe, New Brunswick, NJ, Rutgers University Press, 1991.

Trombetta, S, Punizione e carità [Punishment and Charity], Bologna, Il Mulino, 2004.

Zedner, L., Women, Crime, and Custody in Victorian England, Oxford, Clarendon Press, 1991. 